\title{
Specters of Qingzhen: Marking Islam in China
}

\author{
Guangtian $\mathrm{Ha}$ \\ Department of Religion, Haverford College, Haverford, PA, USA \\ gha@haverford.edu
}

\begin{abstract}
Based on fieldwork in Henan and Ningxia conducted in numerous research trips each lasting from two weeks to two years from 2010 to 2018 , this article argues that in the two decades from the late 1990s to the late 2010s, there was a critical transition in how halal food was marked in China and how the state as well as ordinary Muslims perceived these shifting signs. By explaining the difference between qingzhen and halal signs, and by highlighting the imagistic character of the former, this article shows how local governments both propagated the proliferation of halal signs and soon afterwards saw in these same signs not so much economic prosperity as the threat of global Islam. Therefore, the current crackdown on Islam in China is as much about how Islam is to be visually represented as it is about concerns over sovereignty, ethnicity and religious dissent.
\end{abstract}

\section{Keywords}

Islam - halal - qingzhen - food - China - Hui

Shortly after the landmark China-Arab Axis (Zhong A zhi Zhou, 中阿之轴) was demolished and rebuilt in March 2018 to look more 'Chinese', something less spectacular yet no less visible in Ningxia was forced to change, too. Signs in restaurants, on merchandise, and on placards at food stalls that proclaimed the comestibles on sale to be permissible for Muslim consumption were altered: the Arabic word halal was removed and replaced with qingzhen (清真, clear and genuine). Qingzhen is a word more commonly used among Chinese Muslim Hui; it is also different from the Arabic word halal in its historical trajectory, ideational implication, and most important of all, political ramification. 
Based on fieldwork carried out in Henan and Ningxia in numerous research trips each lasting from two weeks to two years from 2010 to 2018 , this article explains the distinction between qingzhen and halal by highlighting a key point of contention in the recent state crackdown on Islam in China: namely, the visual representations of Islam that appear suspicious in the eyes of an oft-paranoid state intent on stemming ideological dissent. While I do draw attention to the wider suppression of Islam - along with Christianity and lately Judaism ${ }^{1}$ - that includes enforced closure of Qur'anic schools, suspension of informal religious education, cancellation of university academic programs in Islamic studies and so on, ${ }^{2}$ my stress in this article is primarily on the most visibly salient aspect of the campaign. While I do acknowledge the value of examining the religious controversies, environmental concerns, technological dilemmas, and economic pitfalls that often surround the production and sale of halal food (Armanios 2018; Bergeaud-Blackler, Lever, and Fischer 2015; Erie 2018; Fischer 2011; Fischer 2016; Shirazi 2016), ${ }^{3}$ in this article I want to shift our focus to something thus far still underexplored.

I am interested in the recent history of the signs of Islam in China, and how the seeing and decoding of these signs may have shifted over the years. The removal of the Arabic halal signs constitutes one of the most distinguishing marks (along with the demolition of domes that sit atop mosques) of the Chinese state's increasing hostility to Islam. ${ }^{4}$

While one should always take caution in attributing pervasive Islamophobia to the (un)intended work of visual signs, we ought to acknowledge that how

1 This has been covered extensively in international media. See, for instance, https://www. theguardian.com/world/2019/jan/13/china-christians-religious-persecution-translationbible on the Chinese state's repression of Christianity, and http://www.asianews.it/news-en/ Henan,-Kaifeng-Jews-persecuted-along-with-other-religions-46272.html on the dire situation of China's small Jewish community.

2 Reports on the humanitarian crisis in Xinjiang are far too many to cite here. Recent reports show that the condition of the Sinophone Hui Muslims is also deteriorating. See https://www.npr.org/2019/o9/26/763356996/afraid-we-will-become-the-next-xinjiangchinas-hui-muslims-face-crackdown, and more recently https://themuslimvibe.com/ muslim-current-affairs-news/china-arrests-hui-muslim-poet-for-speaking-out-against-theuyghur-concentration-camps?fbclid=IwARısE8_M_p_Pj7MCmPCZeKR8BiKvsbEj6T3jEfEO UKXK3 3 AoCbK-VeıUNLt4.

3 In its normative usages, 'halal' appears in roman type; italicization draws attention to its visual, linguistic and symbolic usage.

4 See, for instance, https://www.independent.co.uk/news/world/asia/china-halal-arabicmuslim-islamic-shop-signs-beijing-xinjiang-uighur-a9032771.html. 


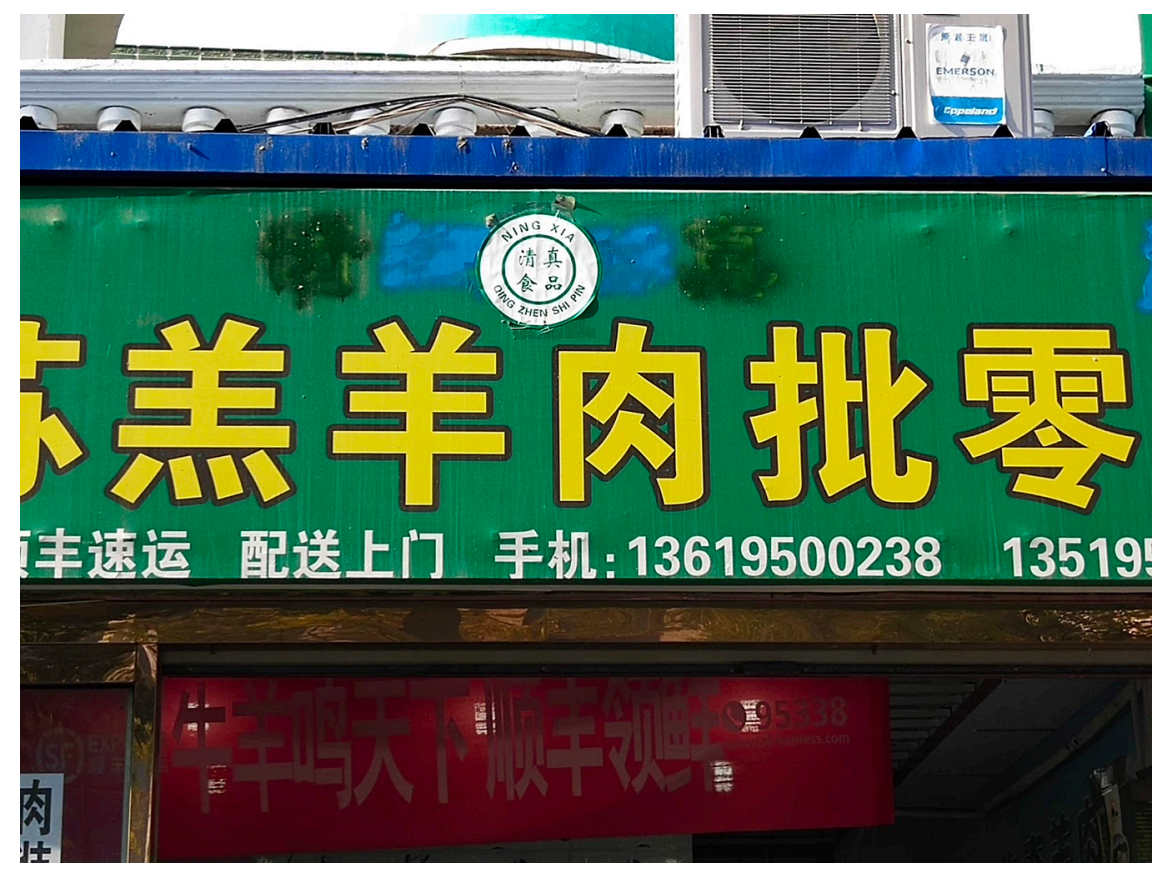

FIGURE 1

one sees and what is offered to be seen can also have a significant impact on how a minority religion is perceived - as much by the minorities themselves as by those purporting to embody the voice of the majoritarian state.

My interest in visual signs is not novel. For the much publicized 'headscarf controversies' across Europe were as much about how Muslims should look and the meanings of those appearances, as they were about contending principles of secularism and state impartiality regarding religion (Ahmed 2011; Alvi 2013; Bowen 2007; 2009; Çınar 2008; El Guindi 1999; Elver 2012; Ha 2017; Macleod 1991; Scott 2007). And the specific context where the viewing takes place - in a public high school with state funding, or a private elite college, or a public university - matters as much as, if not more than who happens to see what, and how some signs are combined with others (a teenage hijab-clad Muslim girl on a skateboard surrounded by cheerful non-Muslim friends may be seen differently from an overworked middle-aged Muslim woman wearing the same hijab pushing a double stroller with two screaming children). However, in few of these controversies concerning women's attire do we see signs of halal food emerge as a major point of contention, though disputes are known to have arisen of schools refusing to provide halal food for their Muslim students 
on grounds of secularism. ${ }^{5}$ The usual question in these cases seems to be whether to allow halal food into certain institutions and in what name. What is usually overlooked, however, is how halal food should be marked out as a distinct category of commodity.

The terms of controversy are somewhat different in China. I know of no cases in which Muslim manufacturers of halal food have been forced by the state to terminate their business. Food repackaged with new signs has been sold openly and with no restraint whatsoever in supermarkets and online stores across the nation. Small street vendors with abysmal hygienic conditions were still allowed to peddle their foodstuffs, insofar as they had scraped their old Arabic signs and adopted a new one officially endorsed and recommended by the state. And my observation suggests no evidence of their businesses being undermined by such alteration of signs. Some companies owned by Hui entrepreneurs were called up by local officials who ordered - at times begged - them to change the registered names of their enterprises, but except for this nominal alteration, business proceeded as usual. While some Hui did bemoan the loss of commercial opportunities in the international halal market as a possible consequence of their change of signage, they were quick to realize that even before the change was enforced, halal food from Ningxia not to mention Henan - had barely reached beyond the domestic market. In other words, while one should not underestimate the drastic impact and massive scale of the crackdown, even where it seems fairly severe, we find a more pronounced stress on the visual marking of halal food than on the actual manufacturing or circulation of the food itself. The state seemed less perturbed by people's dietary preferences than it was by how foods that catered to these preferences should appear. ${ }^{6}$ Thus, signs and how they are perceived - by whom and in what contexts - constitute for us a special vantage point to re-examine the nature of China's recent repression of Islam (cf. Erie 2018).

This article argues that traditional Arabic-language signs in use by the Sinophone Hui - which often contain the Chinese characters for qingzhen - are perceived by many, if not most of them more as images than as words. Many Hui look upon Arabic words positively as jingzi, 'script for the classics', but have no understanding of their meanings. Among the older generations, especially, there

5 https://www.theguardian.com/world/2015/oct/13/pork-school-dinners-france-secularismchildren-religious-intolerance.

6 This is not to deny that with respect to some Muslim minority groups, the state has launched a full-on assault on their religiously informed dietary and sartorial preferences. This is especially the case with the Turkophone Uyghur Muslims in China's western Xinjiang Uyghur Autonomous Region (autonomous, needless to say, only in name). 
was a clear reverence for all Arabic writings regardless of their content, and the average person's lack of literacy in Arabic (even if able to recite multiple Qur'anic chapters) surely contributed to the mystification and veneration of the script. We have little evidence that prior to the 200os, halal signs (with the slick Arabic word halal being the only or main visual motif on the sign) were ever in wide use among the Hui. The qingzhen signs, many of them adopting a style of calligraphy identifiable as specific to China's Hui Muslims, invoked more of a local conception of Muslim minority than a notion of transnational Islamic community. In some cases discussed in this article, a traditional Arabic-language sign for qingzhen food could symbolize a general Muslimness, regardless of whether the specific context of usage pertains to food restriction.

The introduction of halal signs and their subsequent popularization in the 20oos entailed a significant change: for the first time haliali (哈俩里), a Chinese transliteration of halal, began to enter the common parlance of many ordinary Hui, running parallel to without - as of yet - replacing qingzhen. This wider use of haliali also mirrors another related shift: while previously the traditional Arabic-language signs were grasped as general images indicating Muslimness, the new halal signs are read literally as referring to dietary prescriptions and proscriptions. The Arabic in which they are written is taken as an ordinary language, whose script is neither necessarily nor innately sacred. This relative secularization of the Arabic script took place at the very time when the state began to recognize in these new halal signs a spectral threat of transnational Islam. In other words, while previously the Arabic script was looked upon as sacred images by the Hui, and the Chinese and Arabic calligraphy on the qingzhen signs bespoke a localized sense of Muslimness, once the sacred script becomes a secular language, the state by contrast begins to perceive in this language the shadow of global Islamism. Halal signs played further into this fear by exhibiting a standard modern typeface for Arabic; it no longer appeared in the traditional Hui style of Arabic calligraphy.

This article also shows that the large-scale popularization of the Arabic halal signage in the 2000 s was a government-driven campaign. In fact, both the deliberate celebration of halal labelling in the 2000 s and its more recent suppression are essentially governmental actions. In Ningxia, the equation of halal with qingzhen and the multiplication of Arabic signage were not so much signs of local religious revival, ${ }^{7}$ as they were indications of a local government embroiled in an enthusiastic move to join the world halal market. In the 2000 ,

7 For the general revival of religions in post-1970s China, see Goossaert and Palmer (2011); specifically regarding Islam's revival in China, see Harris, Ha, and Jaschok (2021). 
it was the regional government (zizhiqu zhengfu, 自治区政府) of Ningxia that was the main propeller behind a bold public campaign to establish a halal-certification authority in Ningxia. The hope was to rival the JAKIM of Malaysia in the international market. ${ }^{8}$ Those most committed to this cause were ambitious Hui officials eyeing a chance for prosperity for themselves and for the Hui as a group. Whether they eventually succeeded is a matter over which they had little control. As the political winds shifted, some had to resign to failure. ${ }^{9}$ However, they generated much media coverage and drew a great deal of attention from across the nation, accomplishing a level of visibility that was at first a remarkable boon but quickly mutated into a damning bane. Fieldwork in Ningxia and Henan shows how the movement began at its epicenter and rippled out to a province far removed from western China.

In the following, I will first clarify the distinction between qingzhen and halal, and explain why it is crucial that we retain a distinction between the two terms. I then trace the conversion of qingzhen signs into Arabic halal signs. The purpose of this tracing is to show the extent to which the presumed equation between the two terms is precipitated by a local governmental interest in facilitating a globally-oriented food industry that benefits local producers and increases local tax income. I will examine the moments when this transition entailed its own contradictions and defeated its own causes, as well as those other moments when halal signs did not quite replace the qingzhen signs that persistently clung on.

Before proceeding, however, I also need to clarify that it is not my argument that there is a sharp division between qingzhen and halal signs. The former does not necessarily point always to a completely localized conception of Muslimness, nor is the latter always and invariably associated with

8 JAKIM is the abbreviation for Jabatan Kemajuan Islam Malaysia, or the Islamic Development Department of Malaysia, a governmental branch of the state of Malaysia with the express aim of facilitating halal business and 'regulat[ing] halal in the interfaces between Islamic revivalism, the state, and consumer culture' (Fischer 2011: 2). JAKIM therefore represents direct, unmediated state intervention in the regulation of halal food production in Malaysia; it is broadly recognized across the Muslim world.

9 One particularly detrimental downfall has been that of Wang Zhengwei, former governor of Ningxia and vice chair of the Department of the United Front of the Chinese Communist Party's Central Committee from 2015 to 2016. For about three years from 2013 to 2016 he was promoted from governor of Ningxia to chair of the National Commission for Ethnic Affairs, a promotion considered by many in Ningxia to be a clear message from the Party endorsing his previous policies in Ningxia. All the major shifts in halal food certification this article examines took place when Wang Zhengwei was governor of Ningxia. While one should be wary of attributing political change to the fate of one single high-level Hui official, Wang Zhengwei's temporary fall from grace has no doubt emboldened many Islamophobes in Ningxia. 
transnational Islam. Neither do I believe that all Hui had no understanding of the meanings of the Arabic signs that pervaded their lives before the popularization of halal signs. Pilgrimages and continuous communication with the Islamic world - from the Gulf to Mawarannahr, from North Africa to the Indian subcontinent - must have created among some Sinophone Hui Muslims a general feeling of community with Muslims elsewhere; and the Arabic signs they saw at home would thus inevitably invoke a sense of the umma (the universal Islamic community) that transcended local forms of identity. There is also no reason to think that the new signs have signaled a greater connection to the umma for all Hui. For some Hui with no Arabic literacy whatsoever, even the new halal signs may have been assimilated into the old imagistic grasp of Arabic and thus 'localized' without their implication of the global necessarily undermined.

Thus, though I keep the terms distinguished, I do not wish to sharpen and essentialize a division which is anything but clear-cut. Rather I wish to highlight a significant transition in the two decades between the late 199os and the late 2010s; a transition which explains at least in part the pre-history of China's current crackdown on Islam. This transition has always been messy, equivocal, ambiguous, and, judging from more recent observation, likely reversible.

\section{Qingzhen before halal}

The argument that qingzhen is not halal is not new. Translating it as 'pure and true' with implications of ritual cleanliness and virtuous conduct, Dru Gladney once argued that, "[ $\mathrm{t}$ ] his wider meaning of qing zhen goes beyond the Arabic term halal, as qing zhen is sometimes translated, for it involves much more than food ritually prepared according to Islamic dietary prescriptions. The concept of qing zhen governs all one's life' (1991: 3). While halal as an Islamic legal concept also transcends mere dietary restrictions, Gladney was still right in being wary of conflating the two. Indeed, qingzhen encompasses a way of life and constitutes an ethical compass; true as well is that its use straddles the sublime and the mundane. For centuries, Islam has been denoted as the 'qingzhen teaching' (qingzhen jiao, 清真教). It has been used to name SinoMuslim philosophical treatises (e.g. Ma Zhu's Qingzhen Zhinan, 清真指南, The Qingzhen Compass/Guide) (Ben-Dor Benite 2005; Frankel 2011; Lipman 2016; Petersen 2017; Tontini 2016); it is still being used to translate the term for mosque (qingzhen si, 清真寺, qingzhen temple) (cf. Brown 2014).

We have little evidence that before the 2ooos the Arabic halal sign was ever in wide use among the Hui. Qingzhen signs, on the other hand, were 


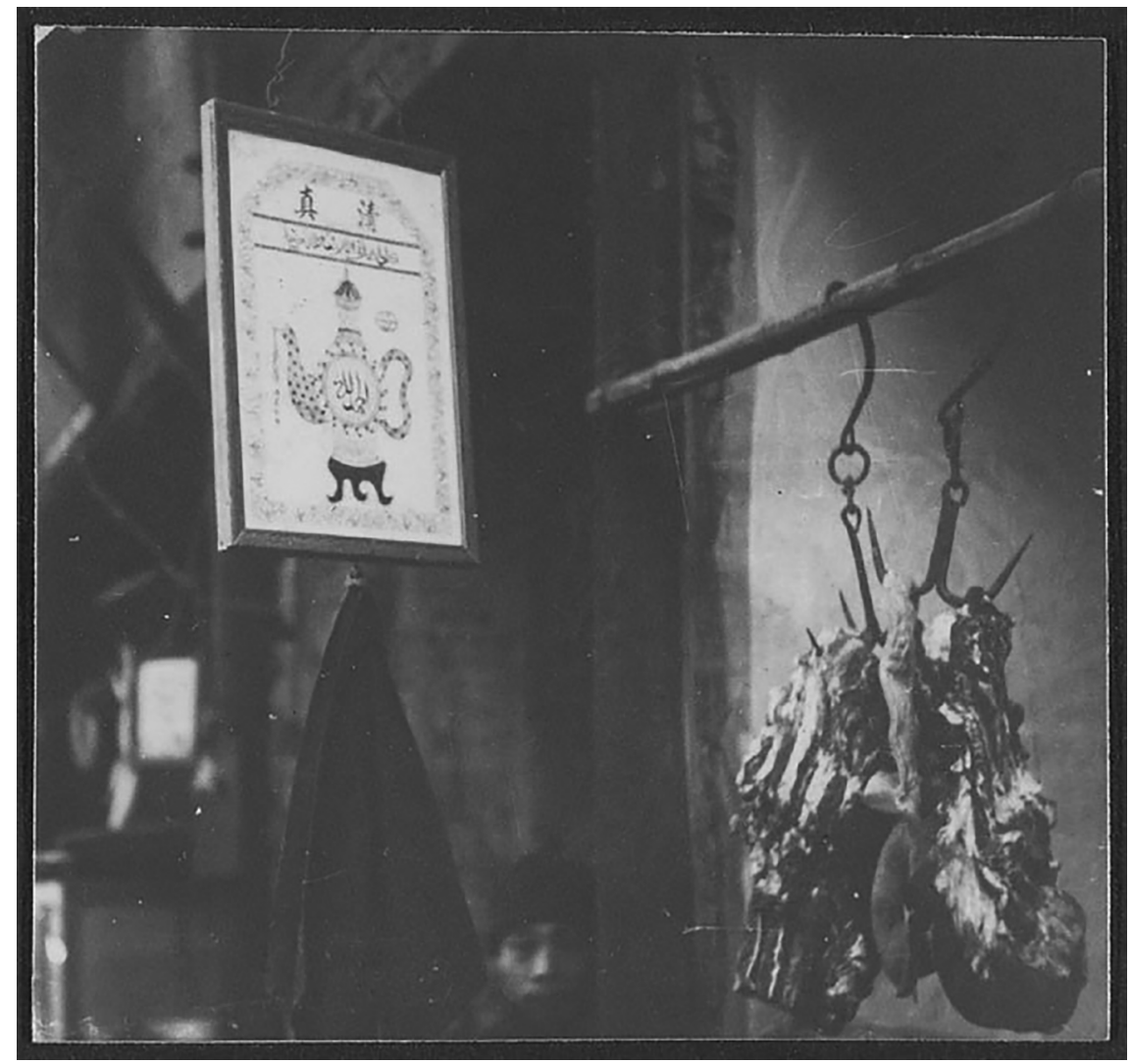

FIGURE 2 Courtesy of Harvard-Yenching Library.

ubiquitous. They were often more than drab reproductions of the two Chinese characters. A photo from a butcher shop in the mid-193os taken by Reverend Claude Pickens Jr. in Wuhan (figure 2), shows a qingzhen sign with the characters framed by floral patterns. The Arabic below qingzhen is unfortunately illegible, while the ewer was prominent in its evocation of ritual ablution. On the body of the ewer is written, not halal - which would have been orthographically simpler - but alhamdulilläh, 'praise be to Allah'. We know not how many ordinary Hui could decode the Arabic inscription. Insofar as we can tell, no Arabic word on the sign translates qingzhen. The butcher could have easily written halal had he preferred to; and yet he did not.

Well into the 1990s, the ewer was still a popular visual motif on many qingzhen signs. An old sign I managed to purchase from a local vendor in Henan (figure 3) displays a reshaped ewer in the image of a considerably less charming teapot, on the body of which is inscribed the name of Prophet Muhammad. 


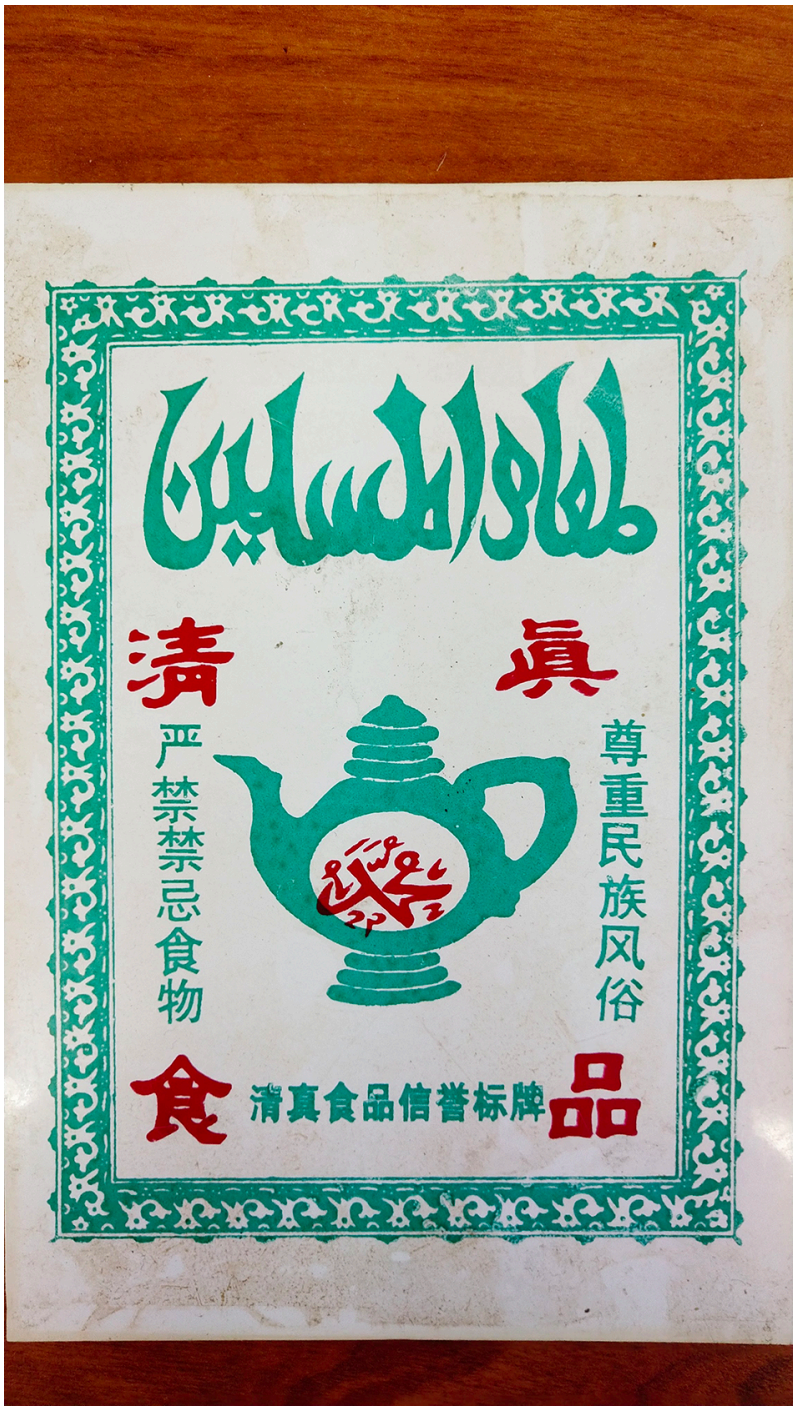

Qingzhen is written in traditional characters as the adjective to 'food' (shipin, 食品), while the Arabic above it says ta'äm al-muslimin, 'the food of Muslims'. The couplet that flanks the ewer reads 'respect [the Hui] ethnic customs; [we] forbid the food forbidden [by Islam]'. Both the couplet and the note at the bottom - 'plate of credibility for [the sale of] qingzhen food' - give out an air of officialdom though no authority is specified. Another 'plate of credibility' I collected that presents a similar pattern (figure 4) has at its bottom, 'under the supervision of Henan Provincial Commission for Ethnic Affairs' (Henan sheng minzu shiwu weiyuanhui jianzhi, 河南省民族事务委员会监制), 

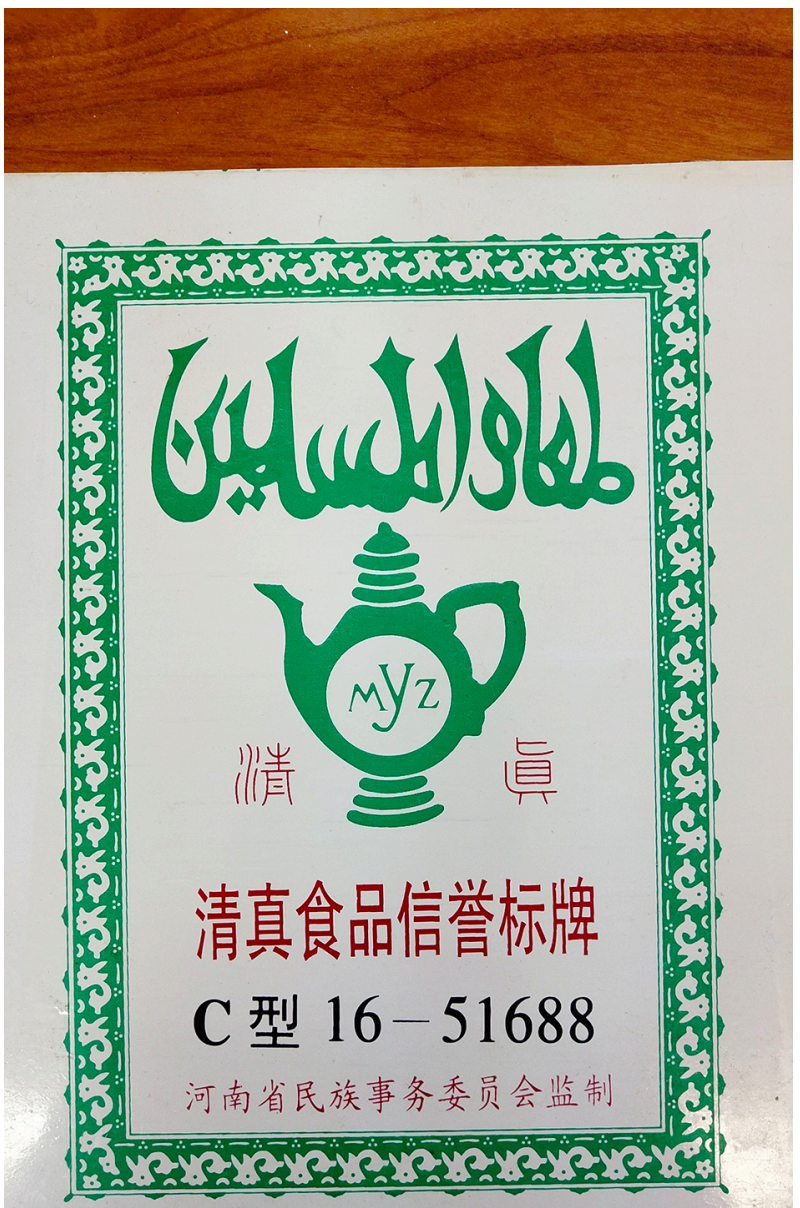

FIGURE 4

while on the body of the ewer is written a stylized abbreviation, MYz. The separated Mz stands for minzu (民族), ${ }^{10}$ while Y indicates yisilan (伊斯兰), the

10 The word minzu has been alternately rendered as 'nationality' and 'ethnic group' in English. Minzu in these modern meanings was initially derived from the Japanese term minzoku, but its later application in the Chinese context was heavily mediated by Soviet nationalities policies. For a comprehensive treatment of minzu see Mullaney (2010). In the late 199os 
modern Chinese transliteration for Islam. A common denotation of the ewer is tangping (汤瓶, soup pot). While some Hui insisted that such ewers were used initially for serving boiling hot broth, in living memory they had never been so used. Tangping, now mass produced in plastic, is used almost exclusively for ritual ablution.

The sign in figure 4 also indicates a gradual shift. 'Type C 16-51688' means that the qingzhen plate belongs to a sub-category of food plates ratified by state power. How many categories the production of food had once been divided into matters no more, as the policy has long since been defunct. However, the fact that the plate had been put on sale points to a phenomenon common in the 20oos: namely, that despite the plates often issued to specific vendors or restaurants, once the said establishment went out of business the plate was at times sold off to the highest bidder, regardless of ethnic or religious identity. The buyer might be the owner of a new restaurant standing on the same spot; or the buyer might have come from somewhere else altogether. Not all plates of credibility bore serial numbers like this one; they were thus even more easily sold to procure a small recompense for a cash-thirsty owner going bankrupt. While no evidence shows that there has been any black market in these plates, the potential circulation of these plates still generated much anxiety among religiously committed Hui and concerned government officials - the latter often Hui, too. During my fieldwork in Zhengzhou (in Henan), at least two mosques in the city center contemplated organizing civil squads to investigate the verity of local restaurants' qingzhen plates. Though they eventually failed to organize under pressure from the local police, the suspicion persisted.

More can be said about the old qingzhen signs. Most old Hui restaurants in the 1980s and 199os used some sort of signage to exhibit their qingzhen status. A commonly used Arabic phrase was ta'äm al-muslimin (the food of Muslims) (figures 3 \& 4); two variations of it that had also been widely used were al-mat'am al-muslimī (the Muslim restaurant) and mat'am al-muslimin (Muslims' restaurant). These phrases are often inscribed in such a manner that the letters are barely legible, and all geometrical rules that normally regulate

and 200os, the debate about a 'second-generation' ethnic policy in China also began as a tinkering with term, and saw a debate about whether minzu was to be best understood as 'nationality' or 'ethnic group' - the former was deemed to suggest a right to political independence while the latter was somewhat 'cultural' in nature and thus de-politicized. For a recent critical review of this debate see Elliott (2015). 


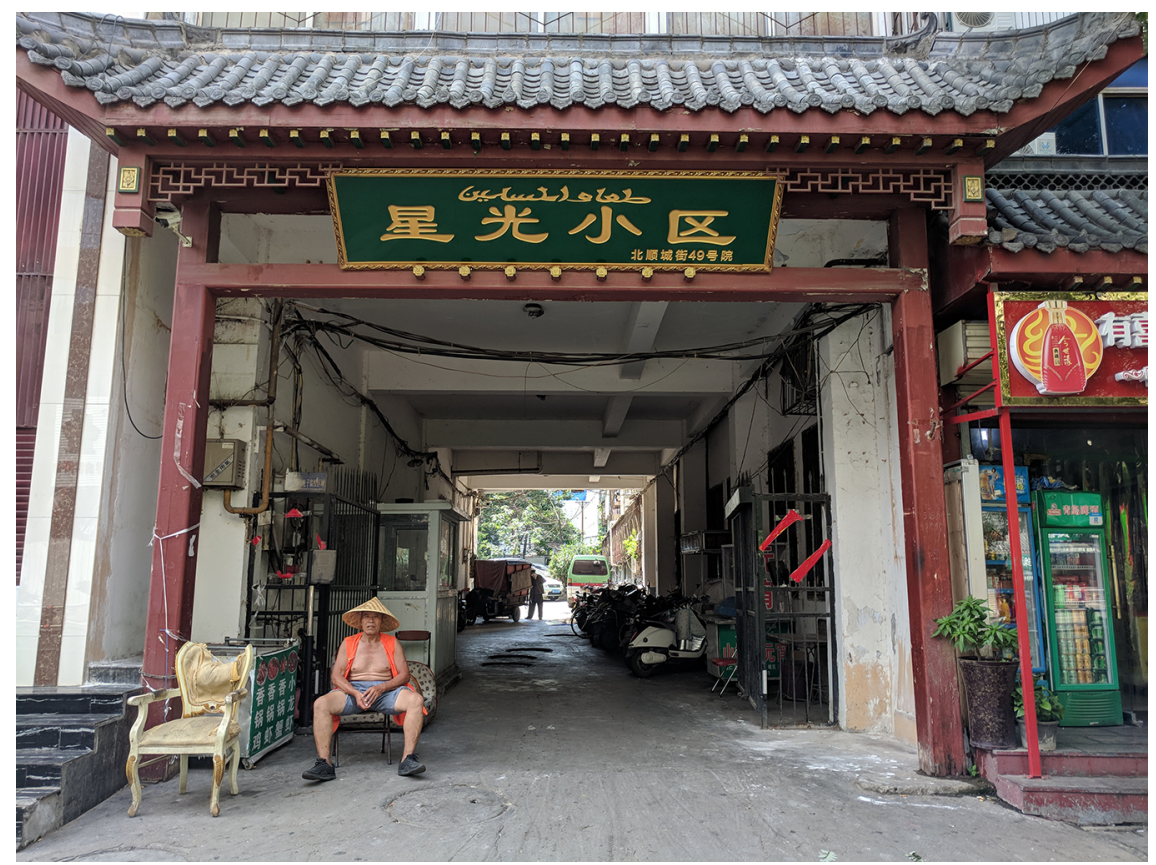

FIGURE 5

Arabic calligraphy are most splendidly defied. By the 1990s such phrases had largely become a sign par excellence in that it was the shape of the letters and their combination into an image, rather than the literal meaning of the words that bespoke qingzhen status. That ța'ām al-muslimin has been rendered into an image is clearest when it is seen outside the context of food. In summer 2018 as I walked down a street at the center of the Hui community in Zhengzhou, among all the newly painted plaques mounted on the façades of restaurants, one stood out bearing the name of a local residential community (figure 5). Above the Chinese name - 星光小区 (Xingguang xiaoqu, Starlight Residence) we read ta'äm al-muslimin. None of the Hui lulling about below this plaque was able to explain to me its meaning, and yet all insisted that it meant most residents living therein were Hui. It seems more plausible that those who had mounted this plaque had taken the phrase to be an image that indicated Muslimness or Hui-ness, than they had intended the population living therein to be advertised as 'long pigs for sale'.

In other words, while qingzhen was often written alongside ta'ām al-muslimin in close proximity, it was not meant to be a translation of this or any other Arabic phrase. No ordinary Hui was expected to understand the Arabic script; they were supposed to recognize the image composed of curled Arabic 


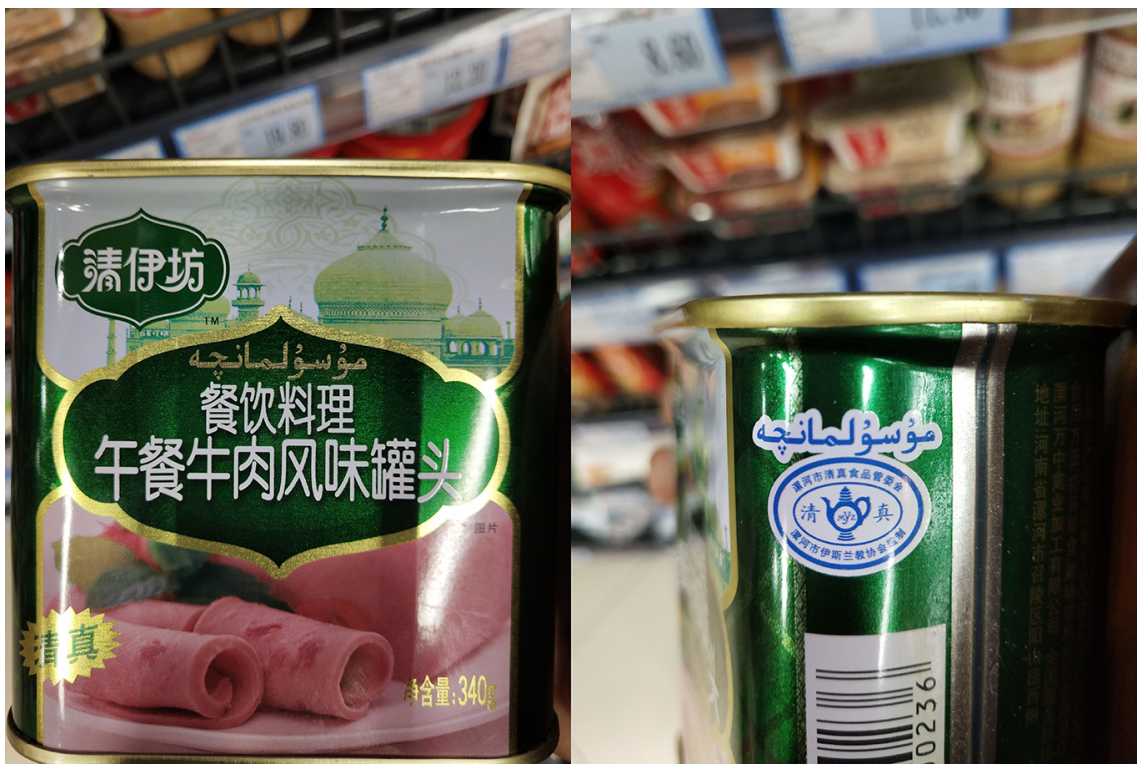

FIGURE 6

letters. Ța'ām al-muslimin had become so much of an image that its meaning as an Arabic phrase had been largely forgotten - only to be resuscitated, for good or ill, after the Arabic word halal began to appear en masse on qingzhen signs.

One of the most telling examples that Arabic script has functioned primarily as an image of Muslimness is that one can also see the Uyghur script used to the same end. In Beijing, Tianjin, Shandong, Hebei, and Henan, I have encountered numerous qingzhen food products with the Uyghur word musulmānche (Muslimized) printed on the tin. In the specific example given in figure 6, the tinned luncheon meat received its certification from the Luohe Islamic Association in Henan. Out of a total population of nearly one hundred million there were, in 2018, only about three thousand Uyghurs in Henan, in contrast to over a million Hui, who constituted the largest minority group in Henan. ${ }^{11}$ Neither in the Luohe Islamic Association nor in the Henan Provincial Islamic Association did we find a single Uyghur member. It is thus unlikely that the Uyghur musulmānche sign was the work of an influential Uyghur Muslim cleric or government official working in Henan - so influential as to convince his Hui and Han colleagues that Uyghur was to be used on official signage. Neither was it plausible that the luncheon meat targeted primarily Uyghur customers,

11 http://henan.people.com.cn/n2/2016/1011/c351638-29120782.html. 
for all other words on the tin were in Chinese. A Uyghur in southern Xinjiang might well have no idea what the product was, and he was more than likely to be suspicious of a tin of meat coming from Henan that claimed to be halal. In 2018, when over a million Uyghur Muslims were reported to have been detained in brainwashing internment camps that the government claimed to be 'vocational training centers', it would be hard to believe that this explicit use of Uyghur on product packaging would have had any appeal. Rather, the use of the script showed the extent to which Arabic and any Arabic-like script had become images that denote a general Muslimness, as opposed to foreign words that express particular meanings. Just as țaām al-muslimin was never translated as musilin shipin (穆斯林食品) on qingzhen signs, so was musulmānche never translated literally as musilin shi (穆斯林式), 'Muslimized' or 'in the Muslim style'. It is remarkable that at a time when many Uyghurs in Xinjiang were forced to learn Chinese and renounce their native language, Uyghur was used openly in a qingzhen sign on a Hui product sold outside Xinjiang. This ceases being a contradiction if we treat this apparent incongruity as indicative of the imagistic nature of Arabic-like script in qingzhen signs.

\section{Qingzhen after halal}

While there had not been a clear Islamic revival among Hui government officials, by the late 2000 s religion was no more a tabooed topic among many of them. In the Henan Provincial Commission for Ethnic Affairs there were Hui cadres who would privately draw on sayings of the Prophet (ahädith) to encourage learning (e.g. 'the ink of a scholar is weightier than the blood of a martyr'), and upon retirement moved into eminent positions in national associations for Hui studies that included both religious luminaries and university academics. Others related fond memories of Islamic festivals and confided in me their desire to fast during Ramadan. Still others, while not being explicitly religious, tended to believe that Hui identity would lose its essence were it to be cleared of any association with Islam and limited to an 'ethnic' category. On one occasion I witnessed a work lunch that embarrassed all present where a few Hui officials were treated to a magnificent abundance of non-qingzhen poultry and lamb by their mostly Han inferiors in a county government office that - ironically enough - managed local Hui affairs. On another occasion, the same group of Hui officials were visibly bothered when a Han official of their ranking compared Han to the 'big brother' (dage) and Hui to a 'little brother' (didi), and said the former had a responsibility to take care of the latter. 'Are we not told that we are equal?!' - one of the Hui officials later complained to me. 
While in neither of these cases was Islam mentioned, they - and many other suchlike encounters - fed into a sense of difference and marginalization pervasive among many Hui officials I came to know in both Henan and Ningxia. This enhanced their already increasing interest in Islam which in turn affected their work in qingzhen supervision.

The equation of halal to qingzhen and the increase in halal's public visual prominence took place primarily in the 20oos. It received a major push in 2008 after the first governmental authority for halal certification was established in Ningxia. While the new institution, officially a department of the Ningxia Commission for Ethnic Affairs, bore the name the Ningxia International Center for Qingzhen Food Certification (Ningxia qingzhen shipin guoji renzheng zhongxin, 宁夏清真食品国际认证中心, hereafter the Ningxia Center), in its terms and conditions qingzhen appeared as the direct translation of halal: 'Qingzhen - or halal - designates those actions and behaviors that accord with the law of Islam.'12 Two years later in 2010 the inaugural session of the China-Arab Economic and Trade Forum (Zhong A jingmao luntan, 中阿经 贸论坛) featured a separate conference on reconciling (duijie) the divergent standards for halal certification between Ningxia and the international market. Boasting fourteen high-level 'foreign guests' from Egypt, Kuwait, Australia, New Zealand, and Argentina - most of them involved in halal certification whether as government officials, academics, or entrepreneurs - the conference brochure included a piece that echoed the views of many Hui officials in Ningxia: it lamented the negligible amount of Ningxia export to the Muslim world and advised more consideration of the living habits' (shenghuo xiguan, 生活习惯) of the Arab world in future trade. In the bilingual pamphlet distributed along with other conference materials, qingzhen never appeared in the English translation, while halal was nowhere to be found in the Chinese text. They ran parallel to one another with no apparent friction whatsoever; the equivalence between the two terms had by this point become so taken for granted in official documents that a brief glossary was no longer necessary. The new Ningxia International Trade Certification Center for Halal Food was an upgraded version of the Ningxia Center founded in 2008; its responsibilities included, inter alia, 'undertak[ing] specifically the international trade certification duty of all halal food products within Ningxia to be exported to Islamic

12 From Ningxia huizu zizhiqu qingzhen shipin renzhen tongze (General Instruction on the Certification of Halal Food in Ningxia Hui Autonomous Region), a document issued by the Ningxia government in 2008. The instruction was officially abolished in December 2017 as the controversy over 'pan-qingzhen-ification' intensified. 
countries and regions.'13 Prior to such official equation of qingzhen and halal, there had surely been more localized and non-governmental attempts at introducing the Arabic halal signs to a wider audience. In the early 200os, some new restaurants in Beijing and Yunnan had already begun to use halal on their signage; such deliberate choice often bespoke an allegiance to a specifically Islamic modernity as opposed to the hegemonic Western version (cf. Gillette 2000). The subtle shift was double: as halal replaced or accompanied qingzhen in an increasing number of signs, Arabic script also gradually began to be recognized as words rather than perceived as images. Qingzhen was old; țaīm al-muslimin, with its imagistic presentation of Arabic, was awfully verbose and outdated; to say nothing of variants like musulmānche. Halal, on the other hand, was recognized internationally and beamed Gulf gold and Malaysian wealth. Qingzhen was the past, halal the future, and ta'ām al-muslimin should be phased out once and for all. And yet none of these was official - until the government made it so.

The new officially advertised halal sign is remarkably bold (figure 7). Trilingual in Chinese, Arabic and English it shows Ningxia at the exact geometric center of an orange-hued map of China. An oversized halal - it is even larger than the map of China! - is partly superimposed on the map, encircled by the words for 'halal food certification' rolled out in all three languages; though, shamefully, the Arabic translation is grammatically incorrect: instead of al-aghdhiyya al-halal (lit. the foodstuffs the halal) it is aghdhiyya al-halal, missing the definite article in front of 'foodstuffs' that is needed in Arabic. Considering the importance of this new logo, the error was especially confounding. No Hui officials in Ningxia I interviewed could read Arabic; and my question about a possible grammatical error in the sign often went unanswered. Interestingly, however, the same error was not replicated in a sample of the new halal certificate the Ningxia government offered for the viewing of its potential international collaborators (figure 8). The inconsistency is somewhat odd and gives away, probably, the sloppiness of a government barely managing to meet the ambitious goal it had set itself. No doubt the design of the new logo and the new halal certificate had benefited from the counsel of experts with knowledge of Arabic (I know some of these experts through fieldwork); and yet the apparent inconsistency highlighted the small role such counsel had played, and it seems likely that the nod to Arabic was largely perfunctory. What is also clear is that in this new logo, the word for food is aghdhiyya instead of ta'a $\bar{a} m$ - reflecting a deliberate linguistic departure from the old ubiquitous 


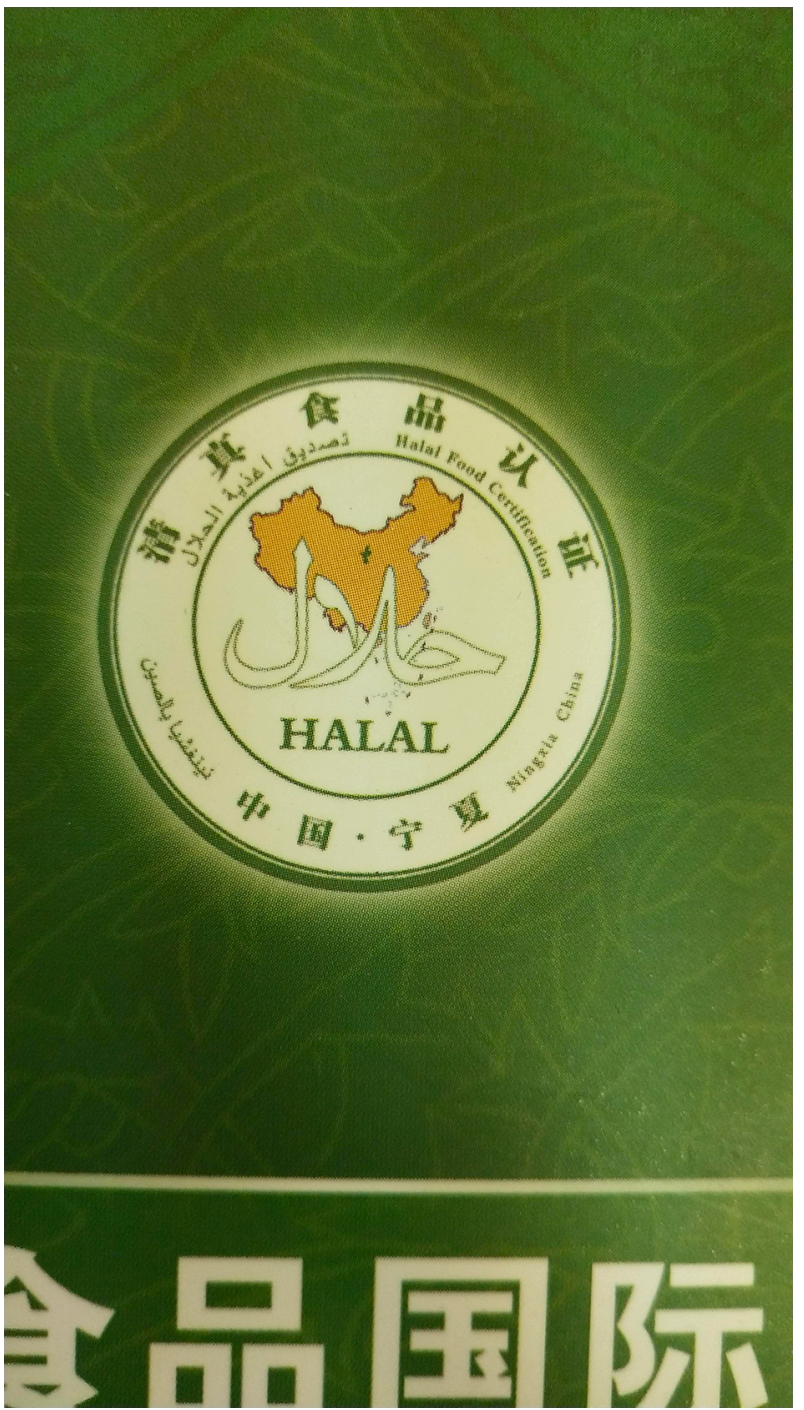

ta'ām al-musliminn. Neither the Malaysian JAKIм logo, nor the Indonesian nor the Singaporean halal logo literally mentions 'food' (figure 9), thus its literality only renders the Ningxia logo all the more exceptional.

During the same period the use of Arabic on non-religious public signage was enthusiastically embraced by the Ningxia regional government. Some officials I interviewed attributed this policy decision to a governmental initiative to render street signs more legible to an anticipated rise in Arabic-speaking traders. Others, especially Hui academics, found this to be largely superficial and 


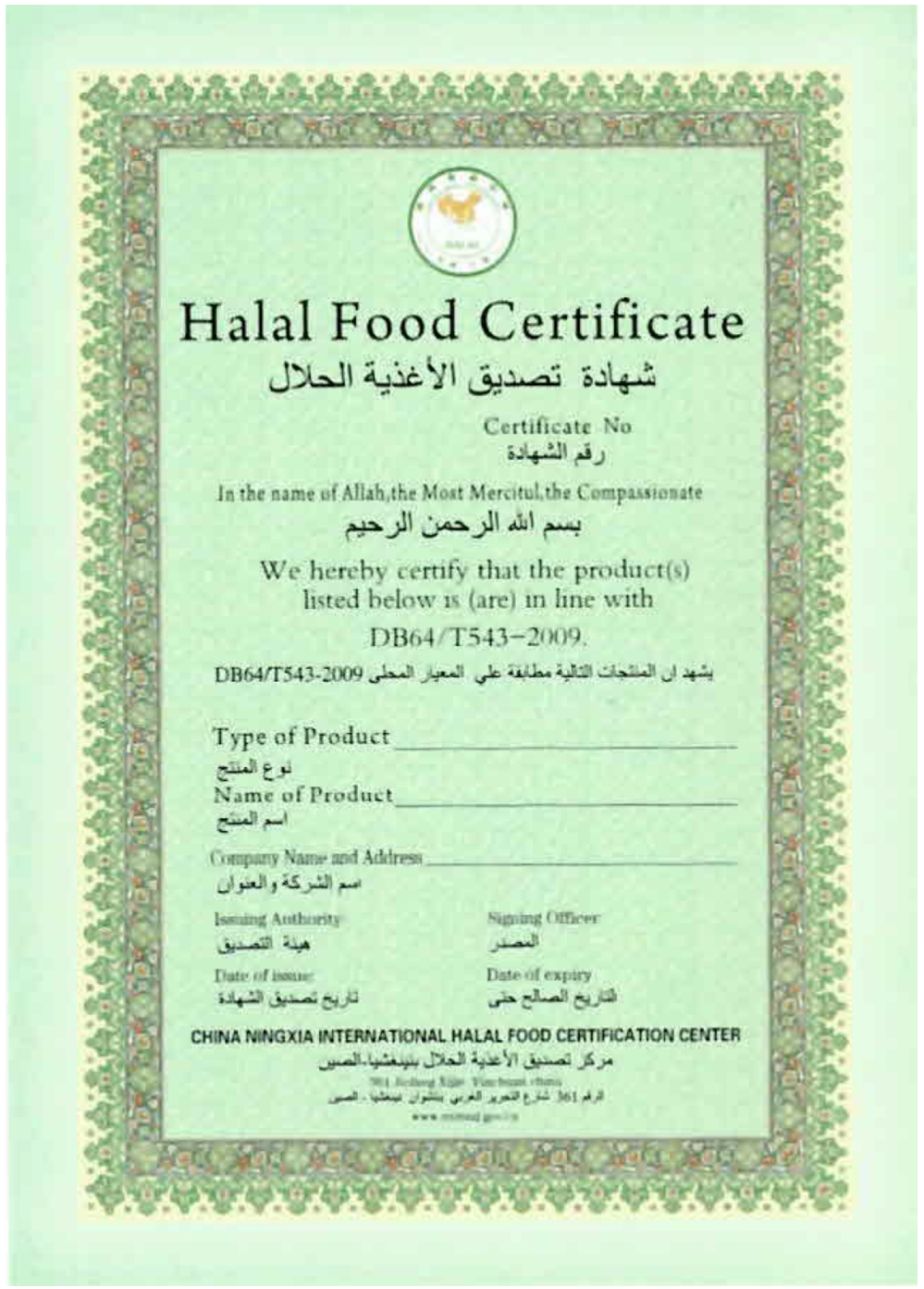

FIGURE 8

a waste of resources. While I did spot Arabophones here and there in Ningxia, such occasions were extremely rare; and the Arab businessmen and state officials invited to participate in economic forums were mostly chauffeured in luxurious limousines or air-conditioned coaches by local drivers assigned by the Ningxia government. That the Arabic-language signs were a show business with only an imagined audience was further confirmed by the faulty Arabic on the signs. Gucheng lu (Road of the Old City) was given a literal translation as tarìq al-madina al-qadima (figure 10), but Jiefang dongjie (Liberation Street 

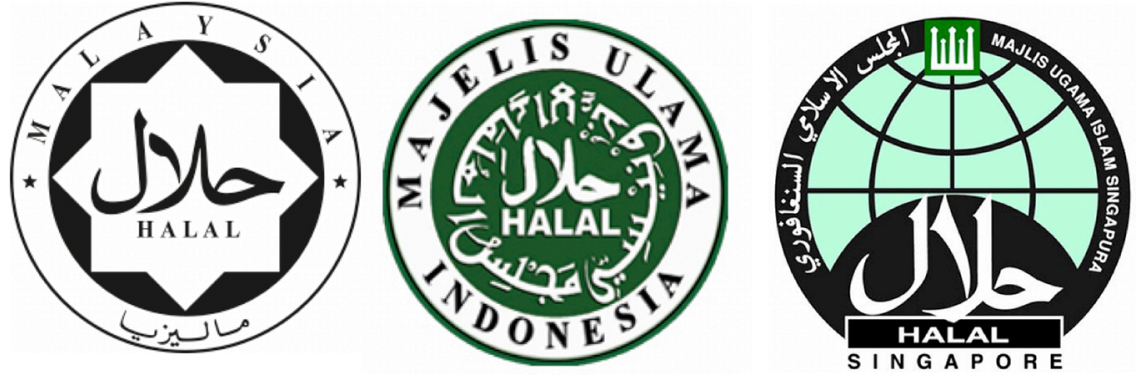

FIGURE 9

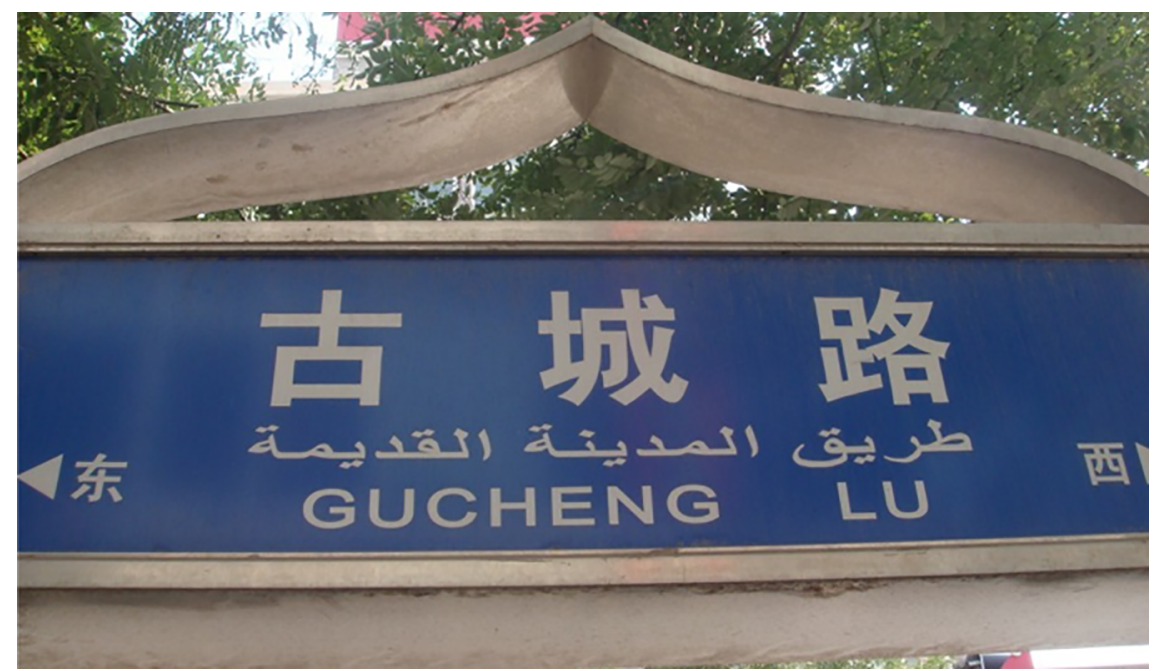

FIGURE 10

East) received a mix of translation and transliteration: instead of translating jiefang (liberation) as tahrīr - rather a common word in Arabic - the sign transliterated it into jïhfāngh, but translated 'east(ern)' as sharqī (figure 11). ${ }^{14}$ At times, the Arabic simply made no sense because of obvious typographical errors (figure 12). In the course of this general trend and certainly emboldened by this governmental initiative, some private businesses also began to put up

14 Is it likely that it was because tahrì was such a loaded word during the time of the Arab Spring - Tahrir Square was the epicentre of the political movement in Egypt that brought down Hosni Mubarak - that the Ningxia government deliberately avoided using it in their signs? This conjecture has never been confirmed by interviews, and I would be surprised if such concerns had a role to play in this more likely haphazardly put-together campaign. 


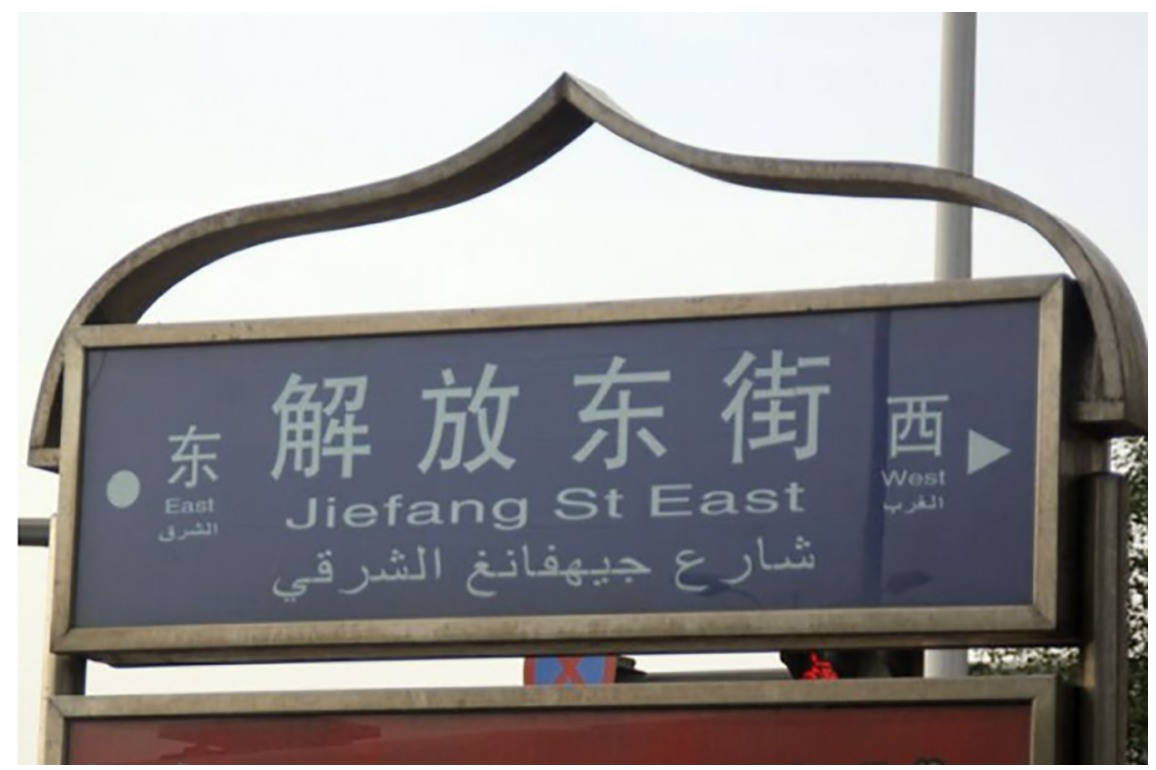

FIGURE 11

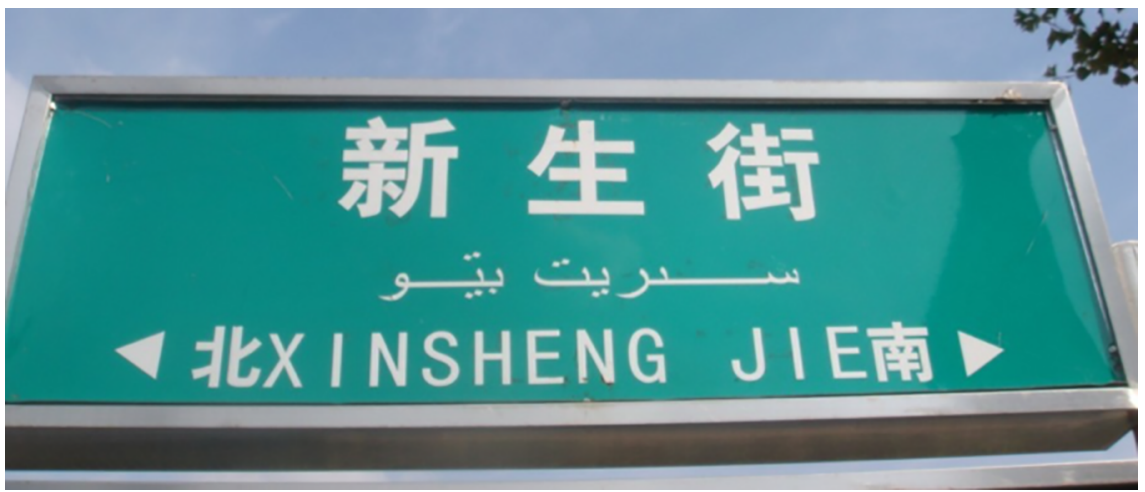

FIGURE 12

Arabic translations of their names, with hotels and guesthouses often spearheading the trend due to the specific nature of their businesses (figure 13). ${ }^{15}$ Whether translating street as shāric or hotel as funduq or road as taríq, it is clear that by now Arabic is no longer a sacred script regardless of meaning,

15 Except for the photo in figure 13 which was taken by the author, those in figures 10, 11, and 12 can be found on an archived webpage at https://jinghuasoft.com/smthview.jsp?board=Pictu re\&id=1105379. The original post has long disappeared; it is thus almost impossible to obtain the permission to reproduce these photos. 


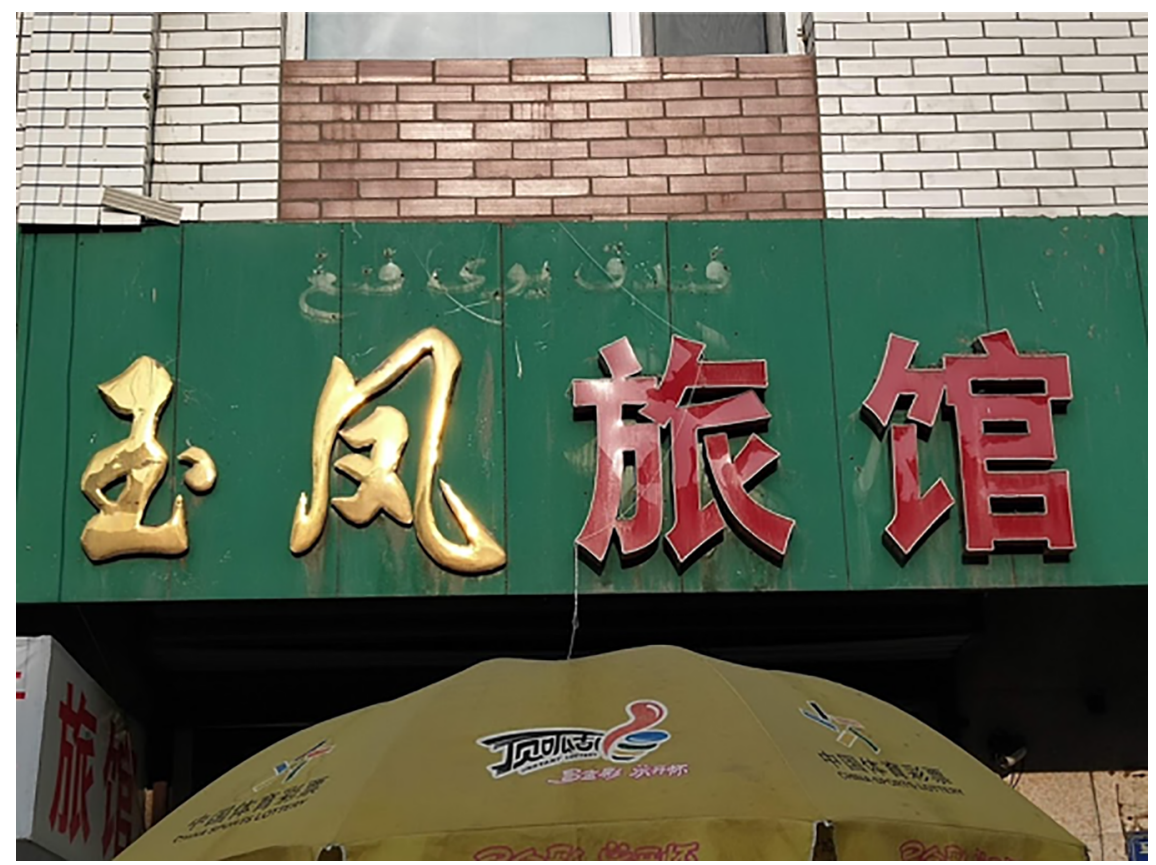

FIGURE 13 Funduq ("hotel") scraped off along with the Arabic transliteration for yufeng, name of the hotel. Photo taken in 2018.

but a common language that can be translated and used publicly in secular signage. ${ }^{16}$

A significant shift occurred as a consequence of this expansive use of Arabic in public signage: namely, that Arabic has now almost re-emerged as words instead of mere images, or those images that used to be so taken begin to (re) gain their life as semantically meaningful segments of Arabic discourse. The popularization of the new halal sign - again, a campaign condoned by the government with a strong regional interest in Ningxia - in part makes Arabic visible as such. While ța'àm al-muslimin was never verbalized in its Arabic pronunciation and invariably qingzhen stood in for it in nearly all daily parlance, from the late 2000 s onwards haliali (哈俩里), a Chinese transliteration

16 We should note that a residue of the imagistic grasp of Arabic still remains even after this shift—attested by none other than the numerous orthographic mistakes we find in the new signs. However, instead of indicating sacredness, or even a generalized Muslimness, the new signs have become completely secularized and indicative less of religion than the prospect of international commerce and a certain consequent cosmopolitanism. I thank one of the anonymous reviewers for pointing this out to me. 
of halal, began to appear on Hui trademarks; ${ }^{17}$ and the word also gradually slipped into the daily parlance of some ordinary Hui. A Hui in Yunnan in her seventies once complained to me about the 'sudden eruption' of new terms in the late 200os. It took her a while to grow comfortable with haliali; at times she would say something was 'qingzhen haliali' or add an explanation to clarify that haliali was qingzhen, for herself as much as for others. From the early 2010s, more Hui began to see a stronger and more literal equation between the idea of qingzhen and the word of halal. Within the space of a few short years, Arabic script seemed to have popped up everywhere; new signs appeared in the streets while old ones re-emerged having shed their imagistic veil. Tendencies to Islamophobia were almost certainly amplified by this new landscape. If even older Hui were disconcerted by the changes, for any Han inclined to zealous nationalism who grew up also taking Arabic as incomprehensible images, the realization in retrospect must have been upsetting, even terrifying. For Arabic letters as image or ethnic calligraphy spells one thing, Arabic as a common language that could bind Muslims around the globe is quite another. When image becomes words, one thus sees no more a localized minority but a suspect with dubious loyalty and international aspirations.

\section{Conclusion}

This article makes the argument that sometime in the late 2000 a critical change occurred among some Hui Muslims in China: the way they read qingzhen signs shifts in such a manner that they now see Arabic words where they previously saw curly shapes. The shapes represented to them a general Muslimness, such reading reinforced by a sacredness traditionally accorded to the Arabic script. Ironically, it was largely due to a governmental campaign keen on tapping into the global halal market that Arabic became at once secularized and politicized; politicized because the new halal signs begin to be read as showcasing Arabic words, and these words are printed in such a standard typeface as to erase any local traces thus more prone to be read as indexing global Islam. Again, I do not believe that the transition is complete, nor do I even think that a majority of the Hui have been influenced significantly by this transition. However, it is still a significant fact that in the latest state

17 See, for instance, the Haliali Qingzhen Food Inc. (http://www.halialifood.com/). Interestingly, despite the growing popularity of haliali, qingzhen refuses to give in. Their coexistence in this company's name with the owner feeling no sense of redundancy shows haliali to be still new to Hui's daily language and thus different from qingzhen. 
campaign to suppress halal signage, even those curly shapes from before have been scraped off to make space for a tasteless monolingual Chinese sign (figure 1). It is likely that, while some Hui may indeed have changed the way they read qingzhen and halal signs, the transition described in this article may in fact be more applicable to the local, and potentially to the central government, too. The Ningxia government saw in halal signs the prospect of profits in a global market; and the same government, defeated by pervasive Islamophobia and a credulous central government in Beijing, later began to view the same signs through the eyes of the latter, and with shocking horror found themselves in a political death trap they had themselves spun. While we must continue to draw attention to the myriad actions taken by the Chinese state to suppress Islam, it is probably also important to note that in some areas that have hitherto gathered much attention, these actions may ultimately amount to much ado about nothing.

\section{Acknowledgements}

Research for this article is funded by the Social Science Research Council (US), The Wenner-Gren Foundation for Anthropological Research, the Leverhulme Trust (UK), and a faculty research grant from Haverford College. I also thank Rano Turaeva and Michael Brose for the workshop on halal food they co-organized in Berlin in 2019, at which an earlier draft of this article was presented. The two anonymous reviewers for Sociology of Islam have been instrumental in helping me reframe some of the arguments and be more accurate in the presentation of facts. I also thank the copyeditor Jennifer Cash for her heroic job. Needless to say, all errors that remain in the text are my sole responsibility.

\section{References}

Ahmed, Leila (2011). A Quiet Revolution: The Veil's Resurgence, from the Middle East to America. New Haven: Yale University Press.

Alvi, Anjum (2013). Concealment and revealment: The Muslim veil in context. Current Anthropology, 54(2): 177-199.

Armanios, Febe (2018). Halal Food: A History. New York: Oxford University Press.

Ben-Dor Benite, Zvi (2005). The Dao of Muhammad: A Cultural History of Muslims in Late Imperial China. London: Distributed by Harvard University Press. 
Bergeaud-Blackler, Florence, John Lever, and Johan Fischer (2015). Halal Matters: Islam, Politics and Markets in Global Perspective. New York: Routledge.

Bowen, John R. (2007). Why the French Don't like Headscarves: Islam, the State, and Public Space. Princeton: Princeton University Press.

Bowen, John R (2009). Can Islam Be French? Pluralism and Pragmatism in a Secularist State. Princeton: Princeton University Press.

Brown, Tristan G. (2014). Imagining consumers: Print culture and Muslim advertising in early twentieth century China. The Muslim World, 104(3): 336-53.

Çınar, Alev (2008). Subversion and subjugation in the public sphere: Secularism and the Islamic headscarf. Signs, 33(4): 891-913.

El Guindi, Fadwa (1999). Veil: Modesty, Privacy, and Resistance. Oxford: Berg.

Elliott, Mark (2015). The case of the missing indigene: Debate over a 'second-generation' ethnic policy. The China Journal, 73(January): 186-213.

Elver, Hilal (2012). The Headscarf Controversy Secularism and Freedom of Religion. New York: Oxford University Press.

Erie, Matthew S. (2018). Shari'a as taboo of modern law: Halal food, Islamophobia, and China. The Journal of Law and Religion, 33(3): 390-420.

Fischer, Johan (2011). The Halal Frontier: Muslim Consumers in a Globalized Market. New York: Palgrave Macmillan.

Fischer, Johan (2016). Manufacturing halal in Malaysia. Contemporary Islam, 10(1): $35^{-52 .}$

Frankel, James D. (2011). Rectifying God's Name: Liu Zhi's Confucian Translation of Monotheism and Islamic Law. Honolulu: University of Hawai'i Press.

Gillette, Maris Boyd (2000).Between Mecca and Beijing:Modernizationand Consumption among Urban Chinese Muslims. Stanford: Stanford University Press.

Gladney, Dru C. (1991). Muslim Chinese: Ethnic Nationalism in the People's Republic. Cambridge: Council on East Asian Studies and Harvard University Press.

Goossaert, Vincent and David A. Palmer (2011). The Religious Question in Modern China. Chicago: University of Chicago Press.

Ha, Guangtian. (2017). The silent hat: Islam, female labor, and the political economy of the headscarf debate. Signs: Journal of Women in Culture and Society, 42(3): $743-769$.

Harris, Rachel A., Guangtian Ha, and Maria Jaschok (2020). Ethnographies of Islam in China. Honolulu: University of Hawai'i Press.

Lipman, Jonathan Neaman (2016). Islamic Thought in China: Sino-Muslim Intellectual Evolution from the 17th to the 21st Century. Edinburgh: Edinburgh University Press.

Macleod, Arlene Elowe (1991). Accommodating Protest: Working Women, the New Veiling, and Change in Cairo. New York: Columbia University Press.

Mullaney, Thomas (2010). Coming to Terms with the Nation: Ethnic Classification in Modern China. Berkeley: University of California Press. 
Petersen, Kristian (2017). Interpreting Islam in China: Pilgrimage, Scripture, and Language in the Han Kitab. Oxford University Press.

Scott, Joan Wallach (2007). The Politics of the Veil. Princeton: Princeton University Press.

Shirazi, Faegheh (2016). Brand Islam: The Marketing and Commodification of Piety. Austin: University of Texas Press.

Tontini, Roberta (2016). Muslim Sanzijing: Shifts and Continuities in the Definition of Islam in China. Brill. 